\title{
HOLOCAUST REMEMBRANCE AND EDUCATION IN THE STATE OF ISRAEL 1948-2000*
}

\author{
BirgitTe Enemark \\ Copenhagen

A BSTRACT In the early years of Israel's existence, the collective memory of the Holocaust was characterized by the schism between the Holocaust martyrs and heroes, emphasizing the bravery and revolt of the few while neglecting the physical suffering of the victims. This understanding was also reflected in the sparse description of the subject in the history textbooks produced by the educational authorities until the late 1970 . In the years to come a more rational and chronological presentation of the Holocaust became noticeable in Holocaust textbooks. However, even though the public interest for the subject increased remarkably it was not made a compulsory and independent subject in the Israeli school system until 1982. Which factors caused this change of attitude towards the Holocaust? The change of attitude did not of course begin overnight. In this article we will explore the development of the Holocaust in the collective consciousness of the Israelis and its impact on Holocaust education in the country. In order to trace this gradual development, we have chosen to focus on milestones in Israeli history; milestones which led from repression of the Holocaust in Israeli society to its adoption as a central event in the consciousness of the Israelis.

In I988, the Holocaust survivor Yehuda Elkana wrote a controversial article in an Israeli newspaper, stating that

[there is] ... no more important political and pedagogical task for the leaders of [Israel] than to side with life, dedicate themselves to the future, and not deal constantly with the 
symbols, ceremonies and lessons of the Holocaust. ${ }^{1}$ They must eradicate the domination of this historical memory over our life. ${ }^{2}$

His plea was for Israel to 'forget' the Holocaust. Yet, what is striking about such a statement is how times have changed. From occupying a peripheral rather than a central role in the consciousness of the Israelis in the early years of statehood, it is, indeed, hard to escape the Holocaust in contemporary Israel. Far from being forgotten, the Holocaust has come to play an increasingly significant role, not only as a cultural icon, but as an absolutely central component in the political debate of the country.

In the following article I will explore the remarkable development of the Holocaust in the collective consciousness of the Israelis and its impact on Holocaust education in the country. In order to trace this gradual development, I have chosen to focus on milestones in Israeli history; milestones which led from repression of the Holocaust in Israeli society to its adoption as a central event in the consciousness of the Israelis.

\section{Holocaust AND HEROISM}

Immediately after the establishment of the State of Israel in I948, Israeli society was too preoccupied to absorb the full scope and significance of the traumatic experience of the Holocaust. The majority of the more than 200.000 immigrants arriving in Israel during the first two years were Holocaust survivors hoping to be met with understanding in their new homeland. The struggle, however, to create a new society in the midst of ongoing wars was of primary importance and gave no room for anything but the heroic myth in the face of the enemy. This resulted in a disproportionate emphasis on the partisan and ghetto fighters' active resistance during the second World War and a contempt for the passivity of the Jewish masses; for those who had gone "like sheep to slaughter". 3 The resistance fighters fit into the Zionist ideals of the active "New Jew", who, unlike the Holocaust-victim, created his own history and shaped his own destiny in 
Israel, liberated from the heavy yoke of diaspora existence. Therefore, a clear distinction was established in the Israeli collective memory between the Holocaust victims and the fighters. It was a distinction that marked armed resistance to the Nazis as heroic and lumped all other aspects of the Jewish experience under the label "Holocaust". "Holocaust" thus became the 'non-heroic' category.

One of the most striking examples of the distorted understanding of the Holocaust in the early years of statehood was reflected in the designation of the official day commemorating the Holocaust: Yom haShoah vehaGvurah ${ }^{4}$, i.e. the Day of the Holocaust and Heroism. In order to incorporate the events of the Holocaust into prevailing historical codes, the date chosen, the 27th day in the Hebrew month of Nisan, was placed as close to the date of the Warsaw ghettouprising (Isth of Nisan, 1943) as possible. The official date, therefore, aimed at memorializing values consonant with those of the new state by linking catastrophe and heroism, thus reinserting the Holocaust in the historical sequence of Jewish catastrophes leading to the redemptive moment of Israel's birth.

Through the twinning of Holocaust and heroism, the Jewish State was able to prevent confrontation with the true horrors of the Holocaust and the destruction of European Jewry. Thus the extermination of Europe's Jews did not, at least for some time, create uproar in. the Israeli consciousness since the Holocaust, according to the early Zionist ${ }^{5}$ leadership, was the ultimate and fatal consequence of Jewish life and existence in the diaspora, an unnatural and futile lifestyle, which the founders of Zionism had despised and warned against approximately so years earlier.

The perception of the diaspora as being antithetical to the new Isreali culture in the making was repeated in the Zionist reconstruction of Jewish history. Thus, in order to make Jewish history compatible with the new Israeli narrative, the early Zionists deliberately leapt over 2000 years of diaspora existence and constructed a national history based on heroic biblical characters, such as the Maccabees. The Jewish diaspora thus became a sad and tragic footnote in Jewish history, while the State of Israel was perceived as the direct continuation of the last period of statehood.in Palestine. 


\section{The first decade of Holocaust education: A proof of Zionist Truth}

Contempt for and lack of understanding of the victims paired with admiration for the resistance fighters was also reflected in the attitude taken by the educational authorities. History textbooks which included the Holocaust were published in Israel from the early fifties, and in those, one could find descriptions of the war, of the Nazi atrocities, and of the resistance of the ghetto fighters. Very little, though, was mentioned about the physical suffering of the Jews. Instead, the resistance of the Warsaw ghetto was described, often terming the ghetto fighters as "Hebrews" or "Israeli youngsters". Their heroic acts, according to the textbooks, served as "a compensation for the shameful surrender of the Jews who were transported to death camps". ${ }^{6}$ In the textbooks the destruction of European Jewry was thus presented as a proof of Zionist truth and explained as the lesson not learned in time: "When Zionism warned and was not listened to", and "When the Zionist movement asked the Jews to immigrate to Eretz Israel, they did not listen, nor learn".?

Although the Holocaust, or rather its heroic chapters, was mentioned in the history textbooks of the period, it was not taught in the schools. One of the reasons for this may be that for many students and teachers, the trauma of the Holocaust was too close at hand to be taught. Furthermore teachers lacked both basic knowledge of the subject and actual teaching programs and curricula. The harsh term, "like sheep to slaughter", was repeated in public forums and often replaced the teaching of the Holocaust in classrooms. Even after the official Holocaust-memorial day was fixed by the Knesset, one third of all schools did not mark the day. ${ }^{8}$ Those that did, performed only the ceremonial rites, unaccompanied by any teaching on the subject.

The informal educational system, on the other hand, such as the kibbutzim and their affiliated youth organizations, made an effort to impart knowledge about the Holocaust, especially its heroic parts, already before and in the early years of Israel's existence. The contribution of the Holocaust survivors to the advancement of perpetuation and documentation of the Holocaust period was incalculable at the time. ${ }^{9}$ For instance, members of Kibbutz Lohamei HaGhetaot, 
founded by survivors of the Warsaw Ghetto Uprising and the concentration camps, established a Holocaust documentation center, Beit Lohamei HaGhetaot - The Yitzhak Katzenelson Holocaust and Jewish Resistance Heritage Museum ${ }^{10}$, on the grounds of the kibbutz in 1949. ${ }^{11}$ Since the r950s it has functioned as a museum, educational center, and research institute, and is, together with Israel's official Holocaust institution, Yad Vashem, the Holocaust museum most frequently visited by the Israeli public in the country.

\section{The EICHMANN TRIAL}

In the three subsequent decades, Israeli society experienced events that precipitated major changes in its understanding of the Holocaust. The first event to bring the Holocaust to the knowledge and consciousness of many Israelis was the public revelation of the stories of survivors in the trial against Adolf Eichmann in Jerusalem in I96. ${ }^{12}$ In the course of the 121 sessions of the trial, 83.500 people visited the courtroom, and hundreds of thousands more followed the trial through the daily radio broadcasts and newspaper coverage.

It has been suggested by literary critic Alan Mintz that the trial with its judicial rituals and "spontaneous eruptions of pathos and rage" 13 resembled mutatis mutandi, a massive passion play in which the members of an entire community take part. However, at the center stage of this play, survivors of the Holocaust appeared for the first time and told their own personal stories. The great majority of them were not ghetto fighters or partisans, but simply 'average' Jews, who had merely survived. For the first time, the Israeli public heard their stories, and this gave rise to greater understanding of and empathy with the victims. From the more than one hundred testimonies, it became evident that in most cases resistance was simply impossible due to terror, starvation, humiliation, and isolation. The prevalent image in Israeli society of the Jews going "like sheep to slaughter" was weakened by the testimonies, and the Israeli public began to comprehend that resistance did not consist solely of physical opposition. However, the submissiveness of the victims was difficult to handle. The poet Haim Gouri, who covered the trial for the paper La'Mer- 
hav, the newspaper of the left-labor party Abdut Ha'avodah, wrote:

I had no desire to listen to this broken, decrepit man go on about his afflictions... I would prefer being present at the $\mathrm{Na}-$ hal (the army pioneer corps) ceremonies taking place today at the stadium and seeing attractive and strong young people. But Morris Fleischman's testimony grabs me by the throat with incredible force and says to me: "Sit down and listen to every last word!". ${ }^{14}$

Even after the Eichmann trial, a gap remained between the Sabra ${ }^{15}$ and the 'average' Jewish victims. Although the individual voices were brought into the open and their suffering legitimized, the trial did not cause an actual identification with the victims. On the one hand, the personal testimonies created greater empathy with the 'average' victims although the armed resistance as manifested by the ghetto fighters and partisans remained the most honorable response to $\mathrm{Na}$ zism and was even strengthened after the Eichmann trial. On the other hand, the testimonies made the event of the Holocaust even more incomprehensible to the Israeli public. Especially the short testimony and collapse of author Yehiel Dinur ("Ka-tzetnik") ${ }^{16}$ caused a great shock among the public. He spoke of Auschwitz as "another planet" and fainted. In his testimony there was something which embodied the estrangement between what had been the "other planet" and the world here and now.

The Eichmann trial thus marks the beginning of a change in Israel's consciousness towards the Holocaust. It was the trial that first broke the silence which had surrounded the subject in the first decade of Israel's existence. However, as illustrated, no actual identification process with the victims occurred. Thus, while the Eichmann trial enabled Israelis to understand that perhaps they could have been victims, it took the Six Day and Yom Kippur Wars to feel that they were victims.

In 1963 , following the Eichmann trial, two new high school history textbooks including substantial sections on the Holocaust were introduced in the school system. They were, however, once again, characterized by a strong emotional and ideological bias, and tended to demonize the perpetrators, accuse the free world of complicity, 
and defend national pride by extolling the fighters of Zionist youth movements while condemning the victims as those who went "like sheep to slaughter".

During the trial, teachers had realized that they lacked both the appropriate teaching materials and a basic knowledge of the Holocaust. However, in spite of the increased interest in the subject among Israeli youth, following the trial, the Ministry of Education did not initiate any methodical program for Holocaust studies. It was suggested that a few lessons be dedicated to the subject in conjunction with the Remembrance Day ceremonies and that it should be incorporated into each subject of the humanities, particularly history and literature. This lead to a situation in which teaching of the Holocaust was still unsystematic, divorced from any historical context, and only dealt with in connection with the official Holocaust Memorial day. Thus, the Ministry of Education did not take advantage of the momentum created by the Eichmann trial to renew the school curricula and include the Holocaust as a separate unit. This reluctant attitude was, however, to change in the course of the Six Day and Yom Kippur Wars.

\section{FROM WAR TO WAR}

The belated Holocaust awareness did not, as previously illustrated, develop overnight, but was affected by events which moved Israeli self-perception and questioned traditional images of national heroism, among these the myth of 'Holocaust Heroism'.

The intense threat of war during the three weeks preceding the Six Day War in 1967 and in particular the disillusion generated by the scaring traumas of the 1973 Yom Kippur War, undoubtedly paved the way for a growing identification with the Holocaust victims. With high losses, more than 2.500 dead in one month, the war emphasized Israel's vulnerability and reminded Israel of the illusory nature of its perception of strength following the Six Day War. The innocence of Israel's first two decades was now challenged by a new and more difficult political and moral reality, and the Zionist narrative began to be transformed. The clear credos of the late 1940s and the early 
1950s were thrown into doubt which emphasized many unanswered questions that had been raised. The reality of the latest war thus enabled Israeli Jews to internalize the view of the Holocaust first presented in the Eichmann trial: not primarily as an exilic phenomenon, whose anti-thesis was physical struggle (associated with the State of Israel), but as a founding event of the State.

\section{Holocaust education following the Six DAY AND YOM KIPPUR WARS}

The heroic representation of the Holocaust in Israeli society dominated the text material about the Holocaust in Israeli schools until approximately the mid-rg7os. However, the frequent comparison of the two last wars with the Holocaust made teachers and educators realize how inadequate and stereotyped their knowledge of the Holocaust was. As educator Nili Keren comments: "All of a sudden, people realized that the Holocaust was never an obligatory subject in high schools, and that in elementary and junior high schools it did not even exist. As an outcome, a whole generation was brought up in Israel without any decent knowledge about this chapter in the Jewish history, but with all the stereotypes inherited from its parents". ${ }^{17}$ This fact created an ongoing criticism of the Ministry of Education from teachers, educators, Holocaust survivors, and politicians, all demanding changes in Holocaust policy, attitude and educational curriculum. Faced with the continuing and increasing criticism, the Ministry of Education could no longer avoid creating a structured Holocaust curriculum.

As a result of the criticism, two new programs ${ }^{18}$ were introduced for secular high schools in the mid- to late r970s. Contrary to the pre-I970 books, which were written by private authors, the two new programs were written with the help of and under the guidance of the Ministry of Education.

The central issue in the two programs was the dilemma of preserving one's human image. The textbooks dealt with two aspects of this issue: the process of losing one's human nature, and the struggle to preserve one's humanity. 
Common to the two new programs was furthermore the belief that the Warsaw Uprising was no longer the sole or main example of armed resistance. Other instances of resistance were mentioned without emphasizing anyone of them in particular. The Warsaw resistance was thus no longer presented as atonement for the guilt of being slaughtered, caused by a failure to heed the Zionist warning, but took its place in the textbooks in proportion to its part in history.

Despite many similarities in the two textbooks concerning content and teaching methods, the degree to which the books challenged the traditional perception of Holocaust education differed. Arye Carmons program, "The Holocaust - A Subject for Highschools", reflected the trend to introduce the universal aspects of the Holocaust. The central question of the program was "not whether it could happen again, but how to foster personal responsibility in order to prevent a potential sliding on that human continuum towards such a recurrence". ${ }^{19}$ Its purpose was "to focus on the student in his search for meaning and the importance of his life as a human being, as a Jew and as an Israeli". ${ }^{20}$ Carmon proposed that the Holocaust was to be studied through an analysis of dilemmas and problems faced by individuals and then examine possible alternatives. This method was also to be applied in the study units on the Germans. Carmon introduced the process of socialization followed by adolescents in Nazi Germany. "The goal of this program was to provide the student with tools which would enable him to reach moral decisions, based on positive values, realizing that immoral decisions based on negative values caused the destruction of his own people". ${ }^{21}$

The educational establishment found this program too radical, too distant from their own concepts of Holocaust education. Despite the call for change, the book had gone too far from the traditional conception of Holocaust education and was cancelled.

Professor and educator Haim Schazker had criticized the existing history textbooks for their overemphasis on emotion and their lack of historical context and methodology. He claimed that the focus on memorial ceremonies, devoid of a conceptual framework, led to demonization of the perpetrators and an inability to sympathize with the victims. Schatzker emphasized historical knowledge of the Holocaust as most important, connecting it both to the Jewish and the 
universal context. He was opposed to instrumentalization of the Holocaust for the purpose of teaching moral values, as Arye Carmon had suggested in his program. As educator Nili Keren notes, despite its new teaching methods, “...it [Antishemiut ve'Shoah] did not challenge the traditional lessons of the Holocaust [it contained substantial sections on the physical resistance and uprising] and ... ended with a chapter which made the connection between the Holocaust events and the establishment of the State of Israel". ${ }^{22}$

The textbook edited by Prof. Schatzker was later replaced by one he co-authored with historian Israel Gutman ("HaShoah Umashmauta", [Holocaust and its Meaning], 1983, revised in 1987). The book has become the most widely used textbook in the Israeli school system throughout the I990s.

Despite the call for changes in the educational arena, the 'Holocaust' did not become a compulsory subject until 1982. From now on, the 'Holocaust' had to be included in the normal curriculum as an independent subject in every Israeli school, and be a compulsory part of the final high school examination. It now became compulsory to teach 30 hours per student about the subject in the high school. To illustrate the change of attitude towards the Holocaust in the educational system, it is important to add that since the early 1980 , questions on the Holocaust have accounted for $20 \%$ of the overall score in the high school diploma examination in history. ${ }^{23}$

\section{LIKUD'S RISE TO POWER: HOLOCAUST POLITIZATION AND FRAGMENTATION}

Outside the educational arena, the Holocaust politization process increased within contemporary Israel, in particular from 1977, when the leader of Likud, Menahem Begin became Prime Minister. Begin lost most of his family in the Holocaust, and this occupied an important place in his world-view. During Begin's reign, the Holocaust became "a cornerstone of the basic creed of the State of Israel and the policies of its government". ${ }^{24}$ In particular, Begin used Holocaust rhetoric $^{25}$ to justify the government's decision to invade Lebanon in 
1982: "[the] alternative is Treblinka and we have decided that there will be no more Treblinkas". ${ }^{26}$ Sympathy and identification with all victims of the Holocaust increased and a more positive attitude towards the traditional culture of diaspora Jewry developed, an attitude that contrasted with Prime Minister Ben Gurion's doctrine of mamlachtiyut ${ }^{27}$, which tended to belittle Jewish diaspora culture.

Throughout the 1980 s and into the I990s, the Holocaust became a political tool, a sort of a political football within an increasingly polarized Israel. With the breakdown of political consensus came also a breakdown in consensus over what the Holocaust meant for contemporary Israel. Particularly, in this breakdown of consensus, was the emerging of two radically different perspectives. Those on the right drew increasingly nationalistic lessons from the Holocaust, while those on the left drew universal lessons.

The 'Left' claimed that the 'Right' abused the Holocaust by stressing only its Jewish character and neglecting completely its meaning for all human kind. The 'Right' claimed that the 'Left' had further reinforced the manipulation of the memory of the Holocaust as a unique historical event unparalleled in human history and had, through its mythic, noncomparative, ahistorical perspective of the event, established a Holocaust complex in Israel.

Some Left-wing scholars saw no viable alternative to the prevalent political Holocaust discourse and called for conscious forgetting. Possibly the earliest formulated attack on Israel's memory of the Holocaust was delivered by Boaz Evron in 1980 under the title: "The Shoah - a danger to the nation". In a summary of his article, Boaz Evron wrote:28

The consciousness of the Shoah has become a very dangerous tool in the hands of the Zionist leadership. The presentation of the Jewish people as the only victim and amanuensis of the crime to the world, increases the anomalous political and economic nature of the State of Israel... The linking of the Shoah with the possibility of a second destruction of the nation in Israel by the Arab states ... turns the idea of Jewish "common destiny" into a grotesque mysticism, completely detached from political reality. Furthermore, this myth frees 
us from all moral restraint towards our enemies. For the choice - annihilation or victory - leaves no room for deliberation. Thus, the Shoah, has, paradoxically, become a real danger of destruction to the nation. ${ }^{29}$

\section{The Holocaust - A COMPUlsory subJect}

Since the Holocaust became a compulsory subject in the educational system, new attitudes and themes have developed and found their place in the textbook material ${ }^{30}$. Instead of presenting the Holocaust through the heroic ghetto fighters in a fight ending with the establishment of the State of Israel, textbooks now gradually told a different story: that of the crisis of the individual in the totalitarian state, the crushing of freedom of choice by political and cultural indoctrination processes; a new attitude, which was reflected in the far more rational, chronological, and contextualized portrayal of Germany and the Germans during the time of the Nazi regime as compared to the textbooks of the period before the mid-r97os. In those one could find descriptions of the German expressed in an extreme and heavily emotionally charged terminology such as "The Nazi devilish evilness", "The crazy Nazi animal at the peak of its fit of madness", "Dark powers", and "Savage brute".

A noteworthy inclusion in today's textbook is the description of the spiritual struggle of religious Jewry in maintaining their human image during the Holocaust. The prevalent glorification of the physical resistance to the Nazis in Israeli society is thus no longer treated as the sole example of struggle, but is rather strongly criticized by several authors. Educator Nili Keren thus notes in her book "Shoah", one of the most recent history text books published on the Holocaust:

The expression "Shoah veGvurah" [Holocaust and Heroism], witnesses to the difficulty of coping with the totality of the terrible experience... Many survivors of the Shoah are of the opinion that the emphasis on the armed struggle ... despite its importance, distorts reality: it diminishes the dreadful horror and nurtures a memory of struggle and revolt. ${ }^{31}$ 
Without getting into details on the teaching of the Holocaust in the National-religious and Haredi communities in Israel, it is worth noting that both fractions emphasize the religious and spiritual aspects in their teaching of the Holocaust, for instance Kiddush HaShem [Sanctification of the Name] and Kiddush HaHayim [Sanctification of life], the pre-war religious European Jewish communities, Hasidism and famous Rebbes. Such aspects have all been completely ignored by the secular educational system until recently. Contrary to the National-religious high schools, the Haredi schools do not participate in the official Holocaust Remembrance Day, insisting that focusing on the physical side of the Holocaust is a Zionist ploy that denigrates the spiritual heroism of religious Jewry during the Holocaust. For the Haredi Jews, true heroism during the Holocaust was in Jewish martyrdom, and spiritual resistance at the portals of the gas chambers. For the same reasons the ultra-orthodox community disapprove of Yad Vashem, which, in accordance with Haredi opinion, pays insufficient attention to another form of heroism, the observance of Jewish law under all circumstances, even if the price was risking death. For this and several other reasons, the Haredi community is presently planning a Holocaust memorial of their own, a replacement of Yad Vashem infused with their own spirit.

In order to give a more complete account of Holocaust education in contemporary Israel, it will, however, be proper to emphasize that several of the kibbutz museums still today tend to present the Holocaust through images of the heroic ghetto-fighters. In the kibbutz museums, established by survivors, their recollections necessarily include their own experiences, their pre-war existence, their resistance and uprising during the war, and finally the survivors' immigration to Israel following the war. As a result, the Holocaust is primarily recalled through images of life and strength, resistance and renewal.

As a final example I will look at a less developed theme in recent textbooks, namely comparability of the Holocaust to other genocides in human history. As an illustration of the limitation of the "other", let us turn to the teaching program produced in the midI990s by Dr. Yair Auron. With the victory of the political left in Israel's 1992 elections, Meretz, the Israeli leftist Zionist party, was given ministerial responsibility for education, and appointed the 
scholar Dr. Yair Auron to develop a new history course on the Holocaust/Genocide that befell other peoples in the 2oth Century. On ro November 1993, the course was officially ratified by the Ministry of Education. The material included textbooks, a teacher's guide, and a general program for training teachers to meet the new challenge. The programme was presented from the outset as part of a larger history curriculum in which schools had the choice of whether or not to include the programme, and pupils could decide whether or not to register for it. The special commission of the Ministry of Education favoured the teaching of the new course since "...research proves that young people are both ignorant of and indifferent to disasters and acts of genocide committed in the 2oth century, especially to the Gypsies and the Armenians". ${ }^{32}$

It is worth noting that in the textbook and the attached materials, Auron did not present his curriculum as an alternative to the accepted Holocaust curriculum in Israel, nor was the Jewish Holocaust challenged. For the Israeli teachers, Auron wrote in the attached materials: "We stress again: this programme does not intend to replace present programmes dealing with the Holocaust. It does not seek to challenge the uniqueness of the Holocaust". ${ }^{33}$ The programme had a clear moral intention: to educate towards sensitivity to the "other's" suffering. This educational commitment synthesized history teaching and the development of humanistic morality in Israeli youth.

The educational programme was, however, never implemented; it was officially cancelled some days before its formal introduction. In the official statement from the educational authorities it was stated that the program was unsuitable and should be abolished immediately. An alternative program was written at the beginning of the 1996 academic year. It was published as a textbook entitled Minorities in History - the Armenians in the Ottoman Empire.

In the Auron program, the genocide of the Gypsies and Armenians, which he constantly calls "Genocide" as distinct from the Jewish "Holocaust", was presented as a historical fact that had to be learned and whose moral implication had to be elaborated and taught in light of universal humanist morality. In the new program, even in the 
introduction, the fate of the Armenians at the beginning of this century is not presented as historical fact. The programme embraces the concept that there is no room for humanistic moral education in a history lesson. The anonymous author writes the following as if the matter is a debate among neutral, objective experts from various schools of history: "The Armenian, Turkish and Western scholars who have researched this period and the relations between the Armenians and Turks differ on the interpretation of the events that occurred between I9I5 and 1916."34

As we have seen, the Israeli Ministry of Education has transmitted its understanding of the Holocaust through textbooks and other material. Over the past ten years, however, curricula and ceremonies have increasingly focused on the Ministry of Education and Culturesponsored youth voyages to Poland, which have become the most intensive encounter of Israeli youth ( $15-17$ years old) with the Holocaust. Upon their return, the voyage "veterans" become propagators of Holocaust memory and the active core of school ceremonies. The story of their experiences and the photographs they show have become a major force in shaping the narrative and images of the Holocaust for their classmates, siblings, and friends. Television broadcasts images of youth groups at Auschwitz into every living room on Yom HaShoah. These trips thus generate images, which, alongside the original film footage of the camps, greatly influence the way Israelis remember and learn about the Holocaust. Thus, Yair Auron suggests, that "the trip to Poland may become ... the most important educational factor, the most meaningful formative force in the life of Israeli youth". 35

\section{History and purpose of the Poland trips ${ }^{36}$}

The first Ministry of Education youth voyages to Poland date from 1988. Since then the travelling of Israeli youth to Poland has increased steadily, from a few hundred in 1988 to approximately 15.000 in 1997-98. In the introductory statement of purpose, of its General Manager's Contract of January 199I (henceforth, hoze mankal), the Ministry of Education declares: 
Its readiness to encourage and assist interested pupils to visit the remains of the Congregations of Israel and the death camps on Polish soil. We assume that pupils will return from this voyage with stronger links to the history of Israel and its heritage, firmer and more determined to build and assure their future, the future of the people and the State, and prepared to mobilize, to contribute their share, the share of this generation, to guard the future of the nation and the State. ${ }^{37}$

In 1992, when Shulamit Aloni was appointed Minister of Education, she suggested that the Ministry withdrew their sponsorship of the Poland voyages: "The whole matter of flags and parades doesn't appeal to me. I'm afraid that many youths return from there with the sense that power is the most important thing, and I want to bring back the true Jew, humanism. There are too many festivals here around the Holocaust, blows and suffering. Too many manipulations [emphasizing] that we are victims and that we have to be strong". ${ }^{38}$ However, as a result of public outcry, she modified her objection, calling for a commission of inquiry into the educational effects and financial organization of the Poland trips.

Aloni's successor, Prof. Amnon Rubenstein, decided that the trips were to continue, but commissioned a comprehensive review of them. He modified the hoze mankal, placing greater emphasis on the humanistic and universal messages of the Holocaust as well as on intellectual understanding. He introduced two changes in its text:

I. To learn the principles of Nazi ideology, to learn the principles and conditions that lead to its rise and actualization, to acts of cruelty and bestiality unprecedented in human history. To understand the foundation of a totalitarian regime in whose framework Nazi Germany declared a war of annihilation against the Jewish people and murdered a third of our people, while also committing other crimes against humanity. To derive both the national lesson of the need for a strong, autonomous Jewish state, as well as the universal lesson of the obligation to guard and protect democracy and to struggle against all forms of racism.(Revised bozeh mankal, 1994).

Rubenstein also added an additional paragraph: 
2. To learn and understand the complexity of Polish-Jewish relations throughout the common history of the two nations, in both its positive and negative aspects, and to understand the history and heritage of the Jews of Poland also against the background of Polish history and culture. (Revised hoze mankal, 1994).

During his term of office, Rubenstein introduced several other changes in the program. For example meetings with Polish youths became a fixed (though not obligatory) element of the voyages, and more sessions on Nazi ideology and Polish-Jewish as well as general Polish history were added to the guides' preparatory course. However, the basic credo of the trip, prioritizing national goals and the emotional element, remained. In 1996, with the return of a National Religious Party Minister of Education, the trips have continued as before 1992 (when National Religious Party representative Zevulun Hammer was Minister of Education), resulting in even less contact with modern Poland.

As Israeli society fractures along religious/ethnic lines, memory of the Holocaust becomes more important as a uniting force. The Israeli journalist, Tom Segev, suggests that the youth missions to Poland are part and parcel of the government's tendency to glorify strength and to place Israel's actions above moral criticism. He characterizes the ceremonies of the Poland voyages as a cult consisting entirely of "emotion and symbols, and a sometimes bizarre obeisance of ... kitsch and death". ${ }^{39}$ Besides Tom Segev, several post-Zionist historians, such as Adi Ofir and Moshe Zuckerman (a post-Zionist sociologist), have written short articles attacking the voyages from a post-Zionist perspective. ${ }^{40}$ Both depict the voyage as an act of nationalistic brainwashing, and emphasize the need for a non-ritualized, humanistic perspective. Although it is still unknown how the Poland voyages will affect Israeli youth over time, it seems likely that the trips, paired with the lack of comparability and universalization in Israeli Holocaust education, will only intensify what the sociologist, Zygmunt Baumann, has termed "hereditary victimhood". ${ }^{41}$

The promotion of the Holocaust to a social element does not stand completely uncontested. In a study of Israeli high school stu- 
dents, many defined themselves as having a family connection to the Holocaust, although it might only have been a distant family relation, "as if this definition was a kind of entry ticket to Israeli society". ${ }^{42}$ As Jackie Feldman points out, this hints at the emergence of a hierarchy of suffering, where the children of victims may enjoy privileged status as opposed to 'adopted' children. ${ }^{43}$

This search for roots has generated or contributed to a series of phenomena in modern Israeli society, including the "return in repentance" of youths to Jewish Orthodoxy, research into the Sephardic heritage, and recently the rise of the strong Sephardic political party, Shas.

This same impetus prompted descendants of survivors to search for their repressed roots in the Holocaust past. Students asked questions, encouraged their elders to publish their memoirs, and began to search for ancestral remnants in Poland. Dan Bar-On notes:

through my students' interviews ... we learned of instances in which the grandchildren had prepared a family "roots" project in school and thus heard their grandparents' stories about the Holocaust for the first time. Their parents, the survivor's own children, became acquainted with these stories only when they read their children's school reports. ${ }^{44}$

As the memory of the Holocaust continues to be a political and ideological battleground within modern Israel, we find increased interest in and greater identification with the victims of the Holocaust on the part of younger Israelis. ${ }^{45}$ Several studies have shown that while the degree of identification of students (both high school and university students) with the Jewish past and Jewish communities abroad is low, or highly variable, the degree of identification with the Jews of the Holocaust is high. Yair Auron found that nearly $85 \%$ of respondents agreed with the statement: "Every Jew in the world must see himself as if he is a Holocaust survivor" ${ }^{46}$ The identification goes beyond descendants of survivors and has become equally strong among Israeli youths of all family or ethnic origin. Based on a smallscale study conducted by his students at Beersheba University, Dan Bar-On concluded that among high school youths, 
the Holocaust is mobilized into the polarized social and political realities of the late I 980 s. While Right-Wing people mobilized the Holocaust to support arguments such as: "We learned from it that we should be strong, that no one will help us in times of trouble", left-wingers claimed: "We learned to be sensitive to minorities of all groups". ${ }^{47}$

An illustrative example of the different lessons to be to be drawn from the Holocaust at all levels in Israeli society is found in the decision taken by the Israeli Army in 1988 to stop visits by recruits to the Holocaust Museum at Kibbutz Lohamei HaGhetaot. What worried army chiefs was that, on the one hand, "after exposure to the museum's exhibits, some soldiers were inclined towards even greater racism and brutality when on duty in the occupied territories," that "there were ... reports of units in which the soldiers termed themselves 'Auschwitz platoons' and 'Demjanjuks". 49 On the other hand, "other soldiers were inclined to be sympathetic to the occupied populace after seeing the museum, to the point of considering refusing to carry out orders, or even draft resistance schemes". ${ }^{50}$

The close relation and strong identification of Israeli youth with the Holocaust has increasingly become a matter of great concern to several Israeli Holocaust educators. Just as Elkana warned against the domination of the Holocaust in Israeli society 13 years ago, so does an educator at Yad Vashem, paradoxically, likewise warn against the consequences of the strong exposure of the Holocaust. Both in regard to the Israeli youth, and, not the least, to the memory of the Holocaust. According to the educator's thought-provoking message, which will conclude this account, it would be more appropriate:

to leave the Holocaust alone for a while and consider the effects of the immense Holocaust consumption in contemporary Israel on the memory of the Holocaust. Our contemporary obsession with the Holocaust may not do any good to the memory of the Holocaust, as we often claim ... on the contrary it may cause considerably damage to this memory ... [as a result] it is time to pause, and reflect, even if the consequences means exposing less people to the subject. ${ }^{5 t}$ 


\section{Notes}

* This paper is based on my master thesis: Shoab Remembrance and Education in the State of Israel. An Analysis of the Development from 1948 to Present Day.

x. Throughout the article the more common English term 'Holocaust' has been preferred over the Hebrew word 'Shoah'. The term 'Holocaust', which was adopted in the Western world and widely used since the I960s, was meant to designate destruction on a monumental and unprecedented scale ("Holokaustos' is the Septuagint term for the 'whole-burnt' sacrifice in the Temple). The Hebrew term 'Shoah', adopted in the early forties, is a biblical term denoting widespread, even cosmic disaster, but without associations to the Temple or its destruction ("they are gaunt with want and famine; they gnaw the dry ground, in the gloom of wasteness [shoah] and desolation" - Job 30:3). See Uriel Tal, Excursus on the term Shoah, 'Shoah': A Review of Holocaust Studies and Commemoration, Vol.r, no.4 (1979), pp.Io-II. In the Yiddish terminology the Hebrew word 'Hurban', which resonates with the memory of past destruction, was used to designate the extermination of the Jews. See David G. Roskies, Against the Apocalypse: Responses to Catastrophe in Modern Jewish Culture [Cambridge Mass; Harvard University Press, I984], p. 26I.

2. Yehuda Elkana, "A Plea for Forgetting", Häaretz, March 2, 1988.

3. After Psalms 44.23: "It is for your sake that we are slain all day long, that we are regarded as sheep to be slaughtered". In the original, the description is laudatory. See also Babylonian Talmud, Gittin $57 \mathrm{~b}$, where the commentary harks back to the period of the destruction of the Temple and refers to children who were taken captive to serve as prostitutes, but leaped into the sea, dying in Sanctification of the [Divine] Name.

The expression "like sheep to slaughter" was first used in a leaflet published by partisan and poet, Abba Kovner, in the Vilna ghetto in I942. In Palestine the expression began to appear in print in late 1942.

4. It should be noted that the religious Zionists were the first to choose a date for the commemoration of the Holocaust. In December 1949, the ashes of Jews exterminated in the concentration camp at Flossenburg were transferred to Israel. Rabbi S. Z. Kahana, director of a department in the Ministry of Religious Affairs, decided that on the roth of Teveth, the day in Jewish tradition for reciting the prayer for all the departed, these ashes should be buried on Mount Zion in Jerusalem. Kahana's proposal was accepted by the chief Rabbinate. The roth of Teverh is also the date of the first siege of Jerusalem by the Babylonian king Nebuchadnezzar. A date which marks the beginning of the traditional sequence of catastrophes shaped by repeated destruction and exile.

5. The term "early Zionists" refers to the Zionists of the so-called mainstream group within the Zionist movement, namely the socialist Zionists. This had been the most dynamic force in Zionism since the early 1920s, and was to a large extent representative of the widest body of opinion in the Zionist camp. For some fifty years, Mapai remained the predominant political party within 
the Jewish community in Palestine, within the Zionist movement in general, and later within the new State of Israel. More than any other factor it molded the Israeli ethos, defining its basic tenants, and shaping the minds of young people associated with it.

6. Ruth Firer. The Treatment of the Holocaust in Textbooks: The Federal Republic of Germany, Israel, The United States of America. Columbia University Press, New York, 1987, p. 18r.

7. Ibid, 179 .

8. Holocaust commemoration ceremonies became a mandatory part of the Israeli school curriculum in 1958.

9. The survivors were also the first to collect archival material that would later serve the historians probing the period, and it was they who threw themselves into the work of preparing the material for the trial of Adolf Eichmann, which opened on April 14, 1961 in Jerusalem.

Io. Yitzhak Katzenelson (1886-1944), poet and dramatist in Hebrew and Yiddish, was originally born in Russia. In Lodz, he opened a Hebrew secular school and served as its principal until the outbreak of the Second World War. During the early years of the war he was in the Warszaw Ghetro where he joined the Jewish partisan organization "Dror" to which the founders of Lohamei HaGhetaot belonged. In the ghetto the organization established an underground gymnasium where Katzenelson was the educator of the young people from "Dror". Later, the founders of Lohamei HaGhetaot established the museum in their beloved teacher's name.

II. Other kibbutz museums and memorials to the Holocaust in Israel include Yad Mordechai, Tel Yitzhak, Givat Haim, Mảale Hahamisha, Mishmar Ha'emek, and Massuah.

I2. Sociological research conducted in the years following the trial reflected a change in attitude among Israelis towards the Holocaust and Diaspora Jewry. In general, the research showed a higher interest in the history of the Holocaust among the youth than before the trial. See Simon N. Herman, Yohanan Peres and Ephraim Yuchtman. "Reaction to the Eichmann Trial in Israel, a Study in High Involvement" Scripta Hierosolymitana 14, 1965, PP 98II8. See also Akiva W. Deutsch, The Eichmann Trial in the Eyes of Israeli Youngsters. Ramat Gan, 1974.

13. Alan Mintz. Hurban: Response to Catastrophe in Hebrew Literature. Columbia University Press, New York. 1984, p. 240.

I4. Ibid. p. 24I.

I5. Native-born Israeli.

I6. Yehiel Dinur, whose nom de plume "Katzetnik" is a Yiddish contraction for "concentration-camp inmate", wrote a series of hyper-realistic novels emanating from his experience in the camps.

I7. Nili Keren. "Ideologies, Attitudes and Holocaust Teaching in the State of Israel-History and Recent Development". In: Remembering for the Future, Pergammon: Oxford, 1988, [pp 1029-1037], p. 1034.

I8. Chaim Schatzker, (ed.) Antishemiut ve'Shoab (Antisemitism and Holo- 
caust). Jerusalem: Hebrew University, Ministry of Education, 1977, and Arye Carmon, Ha'Shoah (The Holocaust). Jerusalem: Ministry of Education, I980, 2 vols.

19. Arye Carmon. "Teaching the Holocaust in Israel". In Ze'ev Garber (ed.). Methodology in the Academic Teaching of the Holocaust, Lanham, 1988, [pp. 75-9r]. p. 84 .

20. Arye Carmon, "Teaching the Holocaust in Israel". See also Arye Carmon, "Teaching the Holocaust as a means of Fostering Values," Curriculum Inquiry 9, no. 3 (1979), p. 209-28.

2I. Keren, "Ideologies..." p. I034.

22. Ibid.

23. In accordance with the Israeli system by which various subjects entitles the student to a certain number of points in the matriculation examinations.

24. Cited in Tim Cole. Selling the Holocaust. From Auschwitz to Schindler. How History is Bought, Packaged and Sold. New York, I999, p. I38.

25. In her analysis of the rhetoric of Menahem Begin's campaign speeches, Nurit Gertz demonstrated how Begin sought to consolidate support by emphasizing the innate dispute of "us" against "them": "The ranks consolidate properly only if there is a large and threatening body standing over "us". That body is "them". The Holocaust was employed to further this end. Nurit Gertz further writes: "In order to make the contrast real, so that it would not become blurred with bridging formulas, it had to be built on the most extreme elements: children and the Holocaust on the one side, and heroism and revenge on the other". (Nurit Gertz. "Few versus many: Rhetoric in the elections speeches of Menachem Begin." Siman Kriah, no. 16-17, 1981, pp. 106-I14 [in Hebrew].

26. Cited in Cole. Selling the Holocaust..., p. 138 .

27. Mamlachtiyut ('statism'), a Hebrew term denoting roughly the principle that state interests should be given absolute top priority. The architects of mamlachtiyut (which symbolized heroism, activism, and revolution) viewed the state of Israel as a symbol of the Jewish people's final escape from the misery of the diaspora, and they could not readily fit the Holocaust, the symbol par excellence of this misery, into their new system of myths.

28. Boaz Evron. "Holocaust - a Danger to the Nation." Iton 77, no. 21, May-June, 1980, pp. I2-17 [in Hebrew].

29. The American commentator, Thomas Friedman, went so far as to suggest that "Israel today is becoming Yad Vashem with an air-force". Cited in Cole. Selling the Holocaust..., p. 138 .

30. In this chapter I will mention only textbooks used by the secular primary and lower secondary schools as well as high schools in Israel.

31. Nili Keren. Shoah: A Journey to Memory. Sifrei Tel Aviv, I999, p. 176. [in Hebrew]

32. Ilan Gur-Ze'ev. "The Morality of Acknowledging/Not-acknowledging the Other's Holocaust/Genocide". Journal of Moral Education, Vol. 27, no. 2, 1998, p. 168.

33. Yair Auron (ed.). Sensitivity to Human Suffering: Genocide in the 2oth 
Century. Tel Aviv, Seminar Akibbutzim, 1994, P. 5 [in Hebrew].

34. Israel's Ministry of Education: Minorities in History - the Armenians in the Ottoman Empire. Jerusalem, Ministry of Education, 1996, p. I [in Hebrew].

35. Yair Auron, Jewish Israeli Identity. Sifrit Poalim, Tel Aviv, 1993 [in Hebrew].

36. Information on the Poland Voyages has been obtained from Jackie Feldman's Doctoral Degree: "It is my Brothers whom I am seeking". Israel Ministry of Education Youth Voyages to Poland of the Shoah. Hebrew University of Jerusalem, I999.

37. Feldman, Chapter 3, p.7.

38. Ibid, Chapter 3, p.9.

39. Tom Segev. The Seventh Million. The Israelis and the Holocaust. Hill and Wang, New York 1993, 488.

40. Adi Ofir. "On Feelings that cannot be expressed, and on lessons that cannot be doubted". Bisvil HaZikaron, no. 7, October 1995, pp. II-IS [in Hebrew]; Moshe Zuckerman. "On Israelis, Poles and Soap". Hed Habinuch, September 1995, Pp. I4-17 [in Hebrew].

41. "The phenomenon of hereditary victimhood ought not to be confused with genetic kinship, or with family tradition preserved through parental influence over the educational setting. Hereditary in this case is mainly imagined, acting through the collective production of memory and through individual acts of self-enlisting and self-identification. Thus the status of "Holocaust children", that is of hereditary victim, is open to every Jew, whatever his or her parents might have been "doing in the war". Zygmunt Bauman. "Hereditary Victimhood: The Holocaust's Life as a Ghost" Tikkun, vol. I3, no. 4, JulyAugust 1998, Pp. 33-38. (Quote, p. 36)

42. Dan Bar-On. Fear and Hope. Harvard University Press, Cambrigde \& London I995, p. 28.

43. Hierarchies of suffering have often been witnessed among survivors, where concentration camp inmates looked down on those who were only in hiding.

44. Bar-On, Fear and Hope. p. 32.

45. This is evident from a comparison of Auron's results (1993) with previous surveys posing the same question, such as Uri Farago, "Consciousness of the Holocaust among youth studying in Israel". Dapim Leheker Tekufat HaShoah, Collection C, 1983. See also: Tel Aviv: HaKibbutz Hameuchad, I984 [both in Hebrew].

46. Auron, 1993, 104.

47. Bar-On, Fear And Hope, pp. I8-19.

48. Shahak, I., "History Remembered, History Distorted, History Denied", Race and Class 30, No. 4 (April-June r989), 80.

49. Cited in Cole, Selling the Holocaust, p. I4r.

50. Shahak, "History Remembered..." p. 80.

51. Personal interview with educator Shafira Rapaport, Yad Vashem, August 2000 


\section{Nordisk Judaistik • Scandinavian Jewish Studies}

\section{PRENUMERATIONSAVGIFTER - SUBSCRIPTION RATES}

Institutioner - Institutional rate

EUR 30

Enskilda • Personal rate

EUR 25

Studerande

EUR IS

\section{BESTÄLLNINGSINFORMATION • ORDERING INFORMATION}

Fyll i beställningstalongen nedan och skicka den till

Please complete the order form and return to

Nordisk Judaistik

Allhelgona Kyrkogata

$\mathrm{SE}-22362$ Lund

Sweden

Or by Fax: +46462224426

\section{BESTÄLLNING • ORDER FORM}

Please enter my subscription to Nordisk Judaistik / Scandinavian Jewrish Studies (ISSN 0348-1646)

\section{口 INSTITUTIONER • INSTITUTIONAL RATE EUR 30 \\ $\square \quad$ ENSKILDA - PERSONAL RATE \\ EUR 25 \\ $\square$ STUDERANDE (only in the Scandinavian countries) EUR IS}

\section{BETALNINGSSÄTT • METHODS OF PAYMENT}

Betala i lokal valuta till något av Nordisk Judaistiks postgirokonton:

Danmark (BG Bank) o 94 or 78 - Finland (Sampo) 8000I5 - 1888946 •

Norge (Den norske Bank) 0806 I914383 - Sverige (pg) I52 Is 29-6

Outside the Scandinavian countries:

Payment to our Swedish bank account (please note, no kind of checks are accepted)

Account no. I52 15 29-6

Postgirot Bank Sweden

SE-IOS o6 Stockholm

Swift: PGSISESS

NAME

ADDRESS

POST/ZIP CODE

COUNTRY

E-MAIL 